\title{
The Futility of Nigeria's Flirtation with American Politico-Systemic Model: The Imperative of Political Culture
}

\author{
Dr. Hillary I. Ekemam \\ Dr. Emmanuel, Iheanocho \\ Department of Political Science, Imo State University, Owerri \\ Email: larryimsu@yahoo.com
}

Doi:10.5901/mjss.2015.v6n3p229

\begin{abstract}
This paper focuses on the politico-cultural explanation for the failure of Nigeria to replicate and sustain the American political type democratic system. It looked as such variables as their history, culture, religion, and political culture itself as its units of analysis. Our aim and objective, is to demonstrate that, like revolution, political systems are outgrowths of political and sociocultural experiences of peoples, and thus may not be sustainably imported or transferred from one country to another. The work is purely comparative, and descriptively analytical. Data for its development were generated from secondary qualitative sources. It concludes that there are multi-pronged factorial disparities in Nigeria's political evolution vis-à-vis the America's, most of which have both historic and politico-cultural nexus. It therefore suggests that Nigeria should look inwards to appreciate its unique history and culture for enduring political model than flirting unsustainably with the American political systemic model which, itself, provides an explanation for its sustenance and relative stability.
\end{abstract}

Keywords: Political Culture, American and Nigeria Democracy, Comparative Politics, ethno-Religious Identities and PoliticoSystemic Model.

\section{Introduction}

It was Sekou Toure who in France in 1959 warned that "to take part in the African revolution, it is not enough to write a revolutionary song; you must fashion the revolution with the people. And if you fashion it with the people, the songs will come by themselves, and of themselves." This paper is about African reality, and the need to adopt African formula in the process of unraveling African contemporary problems. This writer argues that to the extent that African nations are different from the Western European and other developed market economies in terms of their history, culture and political evolution, application of the latter's solutions to the former's predicaments tend to compound and obscure, rather than clarify, and make more manageable the African problems. Thus, application of alien formulas only exaggerate the relative role most people (including Africans) assign to governments and politics in the total setting of their lives. Nigeria as a political entity is used in this study as a case of specific reference.

Since independence, Nigerian policy makers have had this great appetite for the American type political model and have often flirted with it. Some of the variables necessary for understanding Nigeria political system are inherently unique to Nigeria by virtue of its own history. However, others are "imported", presumably as solutions to Nigeria's national predicament of nation-building. And our position is that they have not worked given Nigeria's peculiar realities.

When "political culture" is used as our unit of analysis, the whole essence of the "useful model" assumes more significance. As political scientists, however, we cannot unequivocally argue that any political culture is "superior" than the other rather, each culture has its peculiarity, drawn from its unique historical evolution. Therefore, the question left unanswered is: what have the two political entities in common? Or what makes the American model so attractive to Nigerian policy makers to presuppose the solutions to Nigerian political problems? Clearly, there are some variables shared in common by Nigeria and the United States, viz: English colonialism, heterogeneity of race, multiple of religious faith, party system, and presidential system of government.

To better capture the direction of this paper, few pertinent questions are in order, viz:

a. What are American political culture and its origin?

b. What is the origin of American political culture?

c. What is the history and role of religion and race American and Nigerian political evolution?

d. What are the major consequences of British colonialism in formation of both the American and Nigerian 
political systems?

e. What the history, nature, and role of political parties in the lives of both political systems?

These questions are not totally exhaustive. The choice of variables above is a function of shared traits by the two systems under study. How these questions are answered would certainly throw some light in the discourse and equally serve as a guide for policy makers in Nigeria as they strive to fashion out strategies needed for stabilizing the polity as well as the way the country is organized politically in the future.

\title{
2. Theoretical Framework
}

In their Comparative Politics, Almond and Powell, Jr. (1978:25) state that:

\begin{abstract}
political culture is the set of attitude, and feelings about political current in a nation at a given time; that it has been shaped by the nation's history and by the ongoing process of social, economic, and political activity; that attitude patterns that have been shaped in past experience have important constraining effects on future political behavior. The political culture affects the conduct of individuals in their political roles, the content of their political demands and their response to laws.
\end{abstract}

When Nigeria is placed within the context of the reasoning above, we can argue that as a product of amalgamation and as a "nation" "constructed" from a number of ethnic, cultural, political, and geographical sub-nationalities who had no common bonds, national building would be problematic. Nigeria is a country whose population by and large had little or no loyalties towards another grouping, except for their local and immediate cultural units. Thus, it may become difficult if not impossible to build a stable nation in the strict sense of that word, and to such extent, realize the benefits derivable from sustained national unity. Because of these varying history, belief system, attitude towards a given legal system (as the introduction of the controversial Sharia legal system in Nigeria suggests), often there manifests a seemingly centrifugal force within the polity whose pull tends to disrupt any genuine attempts to forge a stable political system. In fact, while the "melting pot" theory can explain the nature of American system, the "tossed salad" theory will better conceptualize its Nigerian coloration.

Political culture or its absence can therefore provide a modus vivendi for the manifest political instability in Nigeria. Today, new agitations are rife for self-determination for various sub-regional and ethnic groupings like the Movement for the Emancipation of the Niger Delta, MEND, Movement for the Actualization of Sovereign State of Biafra, MASSOB, the Oodua Peoples Congress of the Yoruba ethnic group, and the AREWA, representing the Hausa/Fulani nationalistic interest, respectively.

In addition, the Systems Theory can offer a useful explanation for the inability of the Nigerian state to fashion out a stable political system. Easton (1953), is credited with pioneering the application of this framework to the analysis of political process. Easton "considers the political system as existing with the environment of other systems ... which affects it and are in turn affected by it through continuous transactions and exchanges" (Anifowose and Enemuo, 2008:21). The system, he argues, has interdependent parts of which none can function independent of the rest.

We would rather add that the nature of the demand made of a system has a direct effect on the type and the nature of output to be realized. Now in the Nigeria's scenario, the demand often made of the system tend to be disarticulated having been influenced by divergent cultural and sometimes, clashing religious values, as the introduction of the Sharia legal system into Nigeria's secular constitution has demonstrated. To this end, a non-Moslem Nigerian residing in the Muslim parts can be a victim of Sharia jurisprudence in total violation of his/her rights as protected by the secular order in the non-Moslem legal jurisdictions of the same "nation".

\section{The Origin of American Democracy}

In an elaborate study of democratic politics that distinguishes its fundamental belief from other form of governments, Prothro (1965:52), holds that:

The democratic view of the nature of man is based on the principles of equality and humanism, and progress; the democratic view of the nature of politics is based on the principles of majority rule and minority rights. Democratic theory leans on these beliefs - equality, humanitarianism, individualism, majority rule, minority rights, - and from them gains its enduring appeal.

When the three principal, however general, ideals expressed above namely, equality, political participation, and inalienable rights are extrapolated and subsumed into our analysis, one can deduce the philosophical origin of the 
American democratic system.

One of the impulses that gave rise to the colonists' voyage to the Americas was their dissatisfaction with the absolute monarchy in England. They sought the need for expression and participation in the political decisions that affected their lives. This need was uniformly sought and embraced by all the protesters of monarchic rule who left England for the new world. Granted that Nigeria's founding fathers had sought for independence from England, one can hardly say they equally motivated in that endeavor. Besides, they did so for their individual interests. That means, individuals who had the privilege to succeed the colonial apparatus had self-interest motivations. These were the elements the 'dependistas' referred to as "comprador bourgeoisie". For example, the economic and political order they inherited and maintained found itself invariably at odds with the urgent needs and aspiration of the Nigerian people as was represented by the quest for independence. To what extent can we make the same argument about America's founding fathers? Granted that some of them were the "owning class", and slavery itself for example (which was of course much later) represented equation at odds with the principles of equality, we can nevertheless argue that slaves were not considered humans but "property". Hence slaves, understandably, could not have shared the benefits of equality with their owners.

While there was no unanimity of opinion regarding the need for independence in the Nigerian scene, in the United States, several revolutions commonly referred to as the Glorious Revolution, (Silverman, 1989:61), continuously questioned the authority of the British Crown and its colonial governors, except in England by merchants who benefited from the status quo. In Nigeria on the other hand, certain individuals representing a different cultural religious and political loyalties were opposed to independence. Alhaji Abubaka Tafawa Balewa was opposed to independence until it became evident that Britain would relinquish power anyhow. Balewa was quoted as expressing belief that "independence would not be a feasible object for Nigeria ..." (Richard Sklar, 1963:87,98). His reluctance to accept power was demonstrated by the length of time the Europeans stayed in the northern civil service ever after independence".

\section{The Role of Political Culture}

American political culture traces from the writings of European philosophers as Thomas Paine's "Common Sense" and John Locke's 'Social Contract". Basically, American political culture elevated individual rights over property rights. It also espoused the right of consent of the people - popular sovereignty - and held that the governed and the governors have, in forming the society, reached a social contract in which 'each" gave up some of its rights for the common good; that when it becomes evident that the government does not represent or reflect the popular opinion or consent, the people have the right, under that contract, to withdraw their allegiance or overthrow such government and institute another in its stead. To this end, they consciously rejected monarchical and overbearing system of governance, and embraced popular sovereignty with its attendant recognition of popular consent.

In light of the foregoing, we may now ask: What is Nigerian political culture? From what philosophical doctrines or ideals does it emanate? Who were or are the heroes of the Nigeria's founding philosophy, if any? Answers to these ailing questions are not easily handy except reduced to ethnic, religious, and regional levels of analysis. That is, one may find answers if one were to ask: What is the lbo, Yoruba, or Hausa/Fulani political cultures, respectively?

Therefore, while it may be right to argue that there exists no political culture unique to the Nigerian entity historically, it will nonetheless be wrong to argue that it does not exist within her ethnic, religious, cultural, and nationality boundaries - Nigeria being a "nation" of nations. Furthermore, to the extent they exist only within the identified levels above, how does one reconcile this phenomenon with any notion of over 250 distinct languages which, we might add, represents a commensurate distinct political cultures within this artificial national boundaries.

A school of thought may argue that Nigerian political culture exists within its colonial heritage - reflecting its past colonial relationship. But we hold a contrary view simply because it has not been adequately validated or demonstrated in contemporary scholarship, especially given the obvious overt sub-nationalistic consciousness, courtships, and loyalties in Nigeria. For example, a typical Nigerian is first either "Hausa/Fulani", "Ibo", or "Yoruba" before he/she is a "Nigerian". In contrast, Americans, including those obtaining citizenship through naturalization see themselves first as "Americans" before they are North Carolinians, Texans, Floridians, New Yorkers, or Californians, etc.. He would identify his Spangle Banner flag before he recognizes his neighboring state on the map of the United States or his Confederate Flag. Here, sense of patriotism gravitates around the American flag and Lady Liberty - a symbol of nationhood and freedom.

In his narration of the "Crisis of the Union" Professor Morgan of Yale University alluded to how in an attempt to save the Union a concerned northerner in the U.S. Senate in 1861 beckoned on his countrymen in the name of 'America'; reminded them in a form of battle cry, "Remember the Alamo", of how the sovereignty of the United States, and what history would hand over to their future generations if in the cause of dissent, (brought about by the divisive issue of 
slavery), they were to "lose this great Union",

What may have resembled Dr. Morgan's narration was the "patriotic" cry of Dr. Nnamdi Azikiwe in his "One Nigeria" movement. However, it was later to be argued that Zik's One Nigerianism was basically a flirtation with a unitary system of government as opposed to Awolowo's federalist model - each with its inherent ethnic consciousness.

Political and cultural beliefs, we must note, are all but powerful forces necessary for shaping the agenda and goals of a nation. They affect what people will regard as reasonable and desirable. The stability of the American political system stems historically to many compromises - Connecticut or Great Compromise, Missouri Compromise, the Compromise of 1850; 1877 Wilmot Proviso, Critteden Compromise of 1860, just to name a few. These compromises were all the more significant as embodiment of the founding fathers' intent on forming an enduring Union. In Nigeria, on the contrary, history has shown that "though tribe and tongue may differ in brotherhood we stand" was an utopian slogan as well as a utopian ideal.

The founding as an amalgamation of the Northern and Southern Protectorates was forced on its people for British administrative convenience. There were no known inputs or compromises between the north and the south over any conditions imposed on them by the British. Hence, since the British handed a fragile "national entity" in October of 1960, he North has been opposed to the East as the East, the West (see John Gamble 1987:338). These oppositions are real as no section is willing to make concessions or give up, as is the case with the north, what it considers a "divine right" or manifest destiny of perpetually occupying the seat of government - all based on cultural idiosyncrasies and sectional value system that are often based on abstract principles that mean nothing to other groups. In other words, how does a society or polity evolve a common political culture that would reflect the sensitivities and common value of the generality of its people if their political history and value systems are divergent? It may be germane to argue that while American politico-cultural ideals may not have resulted in a "perfect Union", they have nevertheless, served a useful source of many solutions to their problems of nation-building.

\section{History and Role of Religion}

The "Americans" were torn by religious differences in Europe before their embankment on the great "discovery" of the "new world". Common heritage however allowed different religious groups to thrive relatively side-by-side alongside their need to form a perfect union (once they got to the other side of the shore). This was exemplified during the Great Awakening by the multiplicity of different sects, and before that period, in the settlement of the Penn's Colony of Pennsylvania and Lord Baltimore's Colony of Maryland, (Devine, et al, 1987; Boyer, et al, 1990 ).

But besides religious accommodation, we can also state that historically, American religious beliefs are based on the Greco-Roman and Judeo-Christian tradition. In fact one can argue that Americans shared a common religious beliefs, their different denominations notwithstanding. Nigerians hardly speak of religion in the same sense. Perhaps, Professor Ali Mazrui's (1986) concept of "triple heritage" - traditional, Islamic, and Christianity religions - captures the Nigerian experience. Even in that context, they are just as different faiths and belief systems as one could ever try to understand.

Perhaps, Americans may have envisaged the problems associated with legislating morality, hence providing in their constitution that "government shall make no laws respecting an establishment of religion nor prohibiting the free exercise thereof" - something that has been generally acknowledged as the doctrine of "separation of church and state". In Nigeria's case on the contrary, Sharia law,( an Islamic law), was halfway shoved down the throat of the rest of Nigerians whose Christianity-based laws did not find expression in the secular constitution Nigeria operated at independence. It was the same forces behind the Islamization of the Nigerian constitution that registered Nigeria into the controversial membership of the Organization of Islamic Countries, OIC, during the regime of General Ibrahim Badamosi Babangida.

Because of what it claimed was a "moral" or christening political responsibility, Americans sought to "expand the area of freedom". This was the major underlying principles of its proclamation of "manifest destiny" - to expand "from sea to shining sea". Hence, Indians were by that effort either to be "civilized" christened, assimilated, or uprooted from their lands. The Americans succeeded in that crusade because they carried with them a common political, cultural, and religious ideologies or themes embraced by all. But similar stimuli in Nigeria which came in the form of the Islamic Jihad did not succeed because it did not penetrate into the southern heartlands. Hence its influence was limited predominantly to the northern parts of the country and to some degree in some parts of Yorubaland, especially since the pilgrimage to the Hajj (Mecca) became a status symbol.

How does one, reconcile these factors in order to encourage ones optimism that subscribing to "alien models" would provide solutions to Nigerian problems of nation building? British colonialism is another factor Nigeria shares in common by the two entities under study. This factor might as well have made adoption of American model all the more 
relevant. For example, while the United States fought to get Britain off her back and subsequently stripped herself of all paraphernalia of British social status symbols as Lord, Sir, Dame, or other titles of nobility etc., they continue to be admired and used by some class of Nigerians after fifty years of independence. This class subscribe to the "world view" which holds that Anglo-Saxon nations and peoples represent the apex of civilization and development; that the perceived gap between Anglo-Saxon peoples and Africans in terms of growth and development is a function of certain political arrangements unique to Anglo-Saxon peoples; Hence, those political arrangements, it would seem, irrespective of their irrelevance to the African reality, is, to them, the most appropriate and the only solution to Nigeria's problems of nation building.

\section{History, Nature, and Role of Political Parties}

General Ibrahim Babangida in 1989 announced that in order to defuse sectionalism in partisan politics, his regime would recognize only two political parties, namely, National Republican Congress, NRC, (after the American Republican party) and the Social Democratic party, SDP, (after the American Democratic party). These names are no coincidences in our view. Although analysts are of the view that Babangida had in mind to create ideologically based parties - conservative and liberal, respectively. The question however is: must they be identical to the America's in nomenclature? Some followup questions would be in order here: Does name make political party? Or, does "conservative" make conservatives?

Could there have been any better explanation for the choice of names except perhaps the assumption that they are the major parties of the American democracy; they have been "working" in the United States since 1860, therefore, they ought to work in Nigeria simply by virtue of those assumptions. It sounds syllogistic. One possible, yet ridiculous reason for the choice may well be that every possible name has been used to mobilize popular support in Nigerian politics in the past; that nothing else will be less identical to names which had already been used in the past. Thus, 'imported' names from a "working" democracy will do the magic.

The history of American political parties is a history of Thomas Jefferson's "States' rights" advocacy versus a "strong central government" advocacy Alexander Hamilton. The basic disagreement between these two individuals representing the Federalist, and Anti-Federalists, respectively, did not revolve around personality nor was it ethnic-based like Nigeria's. Rather, it was a conflict of ideas on how each thought the government ought to be organized. By today's standard, it was neither "left" nor "right".

Alexander Hamilton pushed for a strong central government because it was his opinion that since the states were quasi- autonomous, or so, some felt, it would be to the advantage of the Union if the center was stronger than (periphery). Considerations were in terms of security since historical experience showed that colonies could not defend themselves from the English, Spanish, and French military in those formative years. In fact this consideration led the United States to assume an isolationist foreign policy posture in those early days of its independence. Historians and political scientists alike have come to the consensus that even the Monroe's Doctrine was nothing more or less than a self-defense doctrine. It used to be believed that the doctrine's primary consideration was the need to protect Latin America from the imperialistic tendencies of France and Great Britain.

Hamilton also advocated for the loose construction of the constitution in his crusade to strengthen the central government. In that effort he was able to influence the Supreme Court decision when the latter used the "implied powers" doctrine and the "necessary and proper" clause to uphold the establishment of the Bank of the United States against the strict constructionists like Jefferson. Jefferson felt that the Constitution did not expressly authorize the Federal government to establish banks. If the states were supreme vis-à-vis the central government, Hamilton argued, people's allegiance would shift toward the states and in that way incapacitate the central government. Is there any wonder then, that even after the American Civil War, Americans considered themselves as, first, American, before identification with their states of origin?

As a result of these contending ideological views, two political parties emerged. The first election to the presidency of George Washington was only by electoral votes. In fact it was certain that "George" would be elected president even before the end of the Revolutionary War. A footnote is in order here: several political parties have emerged and evaporated during the course of American history depending on their strength and popular appeal. However, they have not taken any deep sectional, religious, or ethnic coloration.

In Nigeria, on the other hand, except for the defunct Peoples' Union of 1908, formed in the wake of protest against British water scheme tax in Lagos, modern political parties emerged out of ethnic youth movements (Sklar, 1963). Even before this period were multiples of partisan groups whose interests and objectives were not well articulated, nor were they sympathetic to any known national agenda. It is beyond the scope of this essay to detail the activities of these splinter groups. However, youth movements in Nigeria were voluntary associations based on kinship or regional affinity, 
e.g., village group, district, or tribe. ( Sklar, 1963: 65-67). The Ibo Union of Lagos was the back-bone of the National Council of Nigeria and Cameroon, with an Ibo native son, Dr. Nnamdi Azikiwe as its leader. The Pan-Yoruba movement or "Ogbe Omo Oduduwa" gave life to the Action Group which was led by a Yoruba native son, Chief Obafemi Awolowo as a parallel partisan group. Only Hausa/Fulani did not as a rule form a tribal union, which may reflect the primacy of Islam as an integrative factor in their society during this period. However, Northern People's Congress, NPC, was later formed with wide Hausa/Fulani following under the leadership of Moslem, Alhaji Aminu Kano and Alhaji Ahmadu Bello, The Saduana of Sokoto who, speaking to a British journalist in the early days of independence stated that he doesn't believe in "one Nigeria" on question of employment of non-Hausa/Fulanis (www.m,youtube.com/watch/v=_WSos ECbcmM) (video retrieved June, 24, 2014; Tordoff, William, 1984:113-115).

One interesting and perhaps contrasting element of the de- development of the Nigerian political parties as opposed to America's is that Awolowo, according to Sklar (1963: 67) advocated among other things:

... the principle of ethnic affinity ... he argued that pan-tribal unity was a necessary condition for political advance ... The educated minority in each ethnic group are the people who are qualified by natural rights to lead their fellow nationals into higher political development. See also (Awolowo, 1947: 64)

Does that sound "elitist"? Awolowo may not be blamed given the level of literacy in Nigeria during this period. However, his fervent belief in tribal loyalty was not conducive for the kind of national question facing the country during those formative years. Similarly, in reference to Dr. Azikiwe, noted that:

\begin{abstract}
notwithstanding his constant affirmation of non-tribal African values, could not be less mindful of the fact that he was identified by his people (the Ibo) with their own national pride. His career typified their growing assertiveness in Nigerian affairs, his clash with the elite leadership of the Youth Movement was both a sign of latent Ibo-Yoruba tension and a major contributing factor to the ethnic hostility that errupted later ... " (Sklar, 1963:55).
\end{abstract}

The British have often been blamed for utilizing the "divide and rule" tactics in their colonial administration of Nigeria. However, to what extent did African political "leaders" contribute to the success of that tactics? In-as-much-as Jefferson advocated for states' right, can we apply the same parallel to understanding the early Nigerian political parties' dichotomy without exaggeration? Nigeria's political parties have continued to take ethnic coloration and flavor. The Action Group and the United Party of Nigeria (UPN) represented the Yoruba (Western) lineage in the First and the Second republics" respectively. The National Council of Nigeria and Cameroon (NCNC) and the Nigerian Peoples' Party (NPP) represented the Ibo (Eastern) lineage in the First and Second "republics", respectively, while the Northern Peoples' Congress (NPC) and the National Party of Nigeria (NPN) represented the Hausa (Northern) political allegiance during the same periods.

Today, APGA is known for its overwhelming Ibo followership, as is AD-turned CAN of the Yorubas before the merger of convenience of few political parties recently in the name of opposition, APC, to the streak of PDP successions at the federal level since 2007. To say the least, these parties have been antagonistic of one another along ethnic lines. While it is common in the United States to come by such questions as "Jimmy who?" (for Jimmy Carter) or "Dan who?" ( for Dan Quarle), in Nigeria on the contrary, one can with a high degree of certainty predict who would run for which office from which ethnic group without a prior scientific study. In other words, old faces have continued to reappear in the Nigerian political scene under different colors or party names representing, for sure, ethnic loyalties.

While it was possible for Ronald Reagan, after having defeated George Bush in the "primaries", to turn around and appoint him to his vice presidency, or George Bush to have appointed Mrs. Elizabeth Dole whose husband, Robert Dole, was his opponent as his labor chief, in Nigeria, on the contrary, such practice would be an aberration.

\title{
7. Conclusion
}

From the fore-going essay and emergent variables of our analysis, this paper concludes that with the benefit of the dissimilar peculiarities, Nigeria's politico-cultural socialization differs from the America's. Similarly, it is easy to conclude that major efforts to form a stable political entity in Nigeria has not realized the major objectives of such efforts, hence demanding a paradigm shift that would respond to the peculiar politico-historic, social, and cultural realities of Nigerians.

As Nigerians and scholars alike begin to address these issues, we may even raise more questions, and hopefully arousing more curiosity for further investigations. Also by looking inwards for a home-grown solutions, we might find useful answers to problems and questions of nation-building. History has shown that as we continue to look outward for ready-made solutions for Africa's problems the origins of which we have not consciously tried to understand, we would 
continue to compound and exacerbate the problems associated with nation-building.

It is, therefore, the responsibility of Africanists, to put on their intellectual amour in search for solutions to the problems of Africa. If we appreciate that these problems are real, then we must equally agree that their solutions are inevitable. It is in keeping with that effort that further research on this phenomenon is not only recommended but inevitable.

\section{References}

Almond, G. Powell, Jr. (1978). Comparative Politics: System, Process, and Policy. Toronto: Little Brown and Company.

Anifowose, and Enemuo (2008). Elements of Politics. Lagos: Iroanusi Publications.

Apter, David (1969). The Politics of Modernization. Chicago: The University of Chicago Press.

Boyer, Paul S. et al (1990). The Enduring Vision: A History of the American People. Lexington: Massachusetts: DC Heat and Company. Devine, Robert A. et al. (1987). America: Past and Present. Glenview, Illinois: Scott Foresman.

Emezi, C.E. and Ndoh, C.A. (1998). African Politics. Owerri: Achugo Publication.

Hinkley, Barbara and Goldman, Sheldon (1990). American Politics and Government: Structure, Processes, Institutions, and Policies. Glenview, Illinois: Scott Forestman.

Huntington, Samuel P. (1968). Political Order in Changing Societies. New Haven, Conn: Yale University Press.

Mazurui, Ali (1986). The Africans: A Tripple Heritage. Toronto: Little Brown and Company.

Nnoli, Okwudibia (1980). Ethnic Politics in Nigeria. Enugu: Fourth Dimension Publishing Co. Ltd.

Organski, A.F.R. (1967). The Stages of Political Development. New York: Alfred Knopf.

Prothro, James and Grigg, Charles M. (1960). "Fundamental Principles of Democracy: Bases of Agreement"in Journal of Politics, Vol. 22 ncc.haifa.ac.il/-rea/articles/disquesed.

Rowstow, W.W. (1981). How Europe Underdeveloped Africa. Washington, D.C.: Howard University Press.

Rossiter, Clinton (2003, ed). The Federalist Papers (by Alexander Hamilton, James Madison, and John Jay). New York: Penguin.

Sklar, Richard (1963). The Nigerian Political Parties: Power in an Emergent African Nation. Princeton, N. Jersey: Princeton University Press.

Sekuo Toure (1960). An Address to the Second Congress of Black Writers and Artists. Rome, Italy in www:panafricanquotes. WordPress. com/2012.

Tordoff, William (1984). Government and Politics in Africa. Bloomington: Indiana University Press.

http:/www.en.wikipedia.org/.../province_of_Pennsil...

http:/www.m.youtube.com/watch/V=_WSOSEcbcmM 